\title{
PEMANFAATAN KAWASAN-KAWASAN TEKNOLOGI PENDIDIKAN DALAM MENINGKATKAN HASIL BELAJAR
}

\author{
Hj. Tatta Herawati Daulae ${ }^{1}$ \\ email : Tattaherawati1961@gmail.com
}

\begin{abstract}
ABSTRAK
Hasil belajar yang baik merupakan cita-cita dan harapan bagi setiap siswa dan mahasiswa, penyelenggara pendidikan, pemerintah maupun masyarakat. Lembaga pendidikan adalah salah satu tempat pencapaian hasil belajar, menyiapkan siswa agar memiliki ilmu pengetahuan, sikap, dan keterampilan. Maka penyelenggara pendidikan harus dapat melakukan berbagai kebijakan dan upaya-upaya pembaharuan dalam bidang pendidikan. Guru dan dosen sebagai pengelola pembelajaran bertanggung jawab mengatur dan melaksanakan pembelajaran dengan baik agar tecapai hasil belajar yang baik. Maka salah satu faktor pendukung dalam mencapai hasil belajar yang baik adalah dengan memanfaatkan kawasan-kawasan teknologi pendidikan dalam aktivitas pembelajaran

Kata Kunci: Kawasan Teknologi Pendidikan, Hasil Belajar
\end{abstract}

\begin{abstract}
Good learning outcomes are the ideals and expectations of every student and collage student, education provider, government and community. Educational institutions are one place to achieve learning outcomes, preparing students to have knowledge, attitudes, and skills. Then the education provider must be able to carry out various policies and renewal efforts in the field of education. Teachers and lecturers as managers of learning are responsible for organizing and implementing learning well in order to achieve good learning outcomes. So one of the supporting factors in achieving good learning outcomes is to utilize educational technology areas in learning activities
\end{abstract}

Keywords: Educational Technology Area, Learning Outcomes

\section{A. PENDAHULUAN}

Salah satu tahapan mengajar yang harus dilalui guru adalah proses pencapaian tujuan. Tujuan yang dimaksudkan adalah hasil belajar yaitu perubahan tingkah laku pada diri seseorang yang dapat diamati dan diukur dalam bentuk pengetahuan.

Pencapaian hasil belajar merupakan suatu target penting dalam pelaksanaan pembelajaran, tidak ada suatu kegiatan yang diprogramkan yang mengabaikan hasil, maka

\footnotetext{
${ }^{1}$ Dosen Institut Agama Islam Negeri Padangsidimpuan
} 
pencapaian hasil dalam kegiatan pembelajaran merupakan unsur penting yang harus di citacitakan dan dicapai. Hasil belajar itulah yang akan mewarnai cara peserta didik bersikap dan berbuat dalam lingkungan sosialnya, baik di sekolah maupun di luar sekolah. Maka salah satu faktor yang sangat mendukung dalam pencapaian hasil belajar adalah dengan memanfaatkan pelaksanaan kawasan-kawasan teknologi pendidikan dalam pembelajaran.

\section{B. TEKNOLOGI PENDIDIKAN}

\section{Pengertian}

Secara etimologi teknologi berasal dari bahasa yunani yaitu tekhne dan logia. Tekhne berarti seni atau keahlian, sementara logia berarti area studi atau ilmu. Secara harfiah tekhnelogia berarti ilmu tentang seni dan keahlian. Kata teknologi juga berasal dari bahasa latin yaitu texere yang berarti membangun atau mendirikan. Pada perkembangannya teknologi dimaknai sebagai proses penciptaan alat dan mesin oleh manusia yang digunakan sebagai sarana untuk meningkatkan penguasaan dan pengolahan bahan-bahan yang ada dilingkungannya. ${ }^{2}$ Istilah Teknologi adalah penerapan keilmuan yang mempelajari dan mengembangkan kemampuan dari suatu rekayasa dengan langkah dan tekhnik tertentu dalam suatu bidang. ${ }^{3}$ Jadi, Teknologi adalah penanganan sesuatu secara sistematis atau penerapan sains untuk memecahkan masalah. ${ }^{4}$

Menurut Kamus Besar Bahasa Indonesia teknologi ialah kemampuan teknik berlandaskan pengetahuan ilmu eksakta yang bersandarkan proses teknis. Dari rumusan ini dapatlah dikatakan bahwa teknologi adalah ilmu tentang cara menerapkan sains untuk memanfaatkan alam bagi kesejahteraan dan kenyamanan hidup manusia. ${ }^{5}$

Teknologi pendidikan didefinisikan sebagai suatu proses kompleks yang terintegrasi meliputi manusia, prosedur, ide, peralatan dan organisasi untuk menganalisa masalah yang menyangkut semua aspek belajar, serta merancang, melaksanakan, menilai dan memgelola pemecahan masalah itu. ${ }^{6}$

\footnotetext{
${ }^{2}$ Imam Sukardi, dkk, Pilar Islam Bagi Pluralisme, ( Solo: Tiga Serangkai, 2003), h. 110

${ }^{3}$ http: // istana ilmu, com/ Pengaruh Teknologi Pendidikan dalam Lembaga Pendidikan dan Pelatihan/ html.

${ }^{4}$ Ibrahim, Teknologi Pendidikan, arti kawasan dan penerapannya di Indonesia, (Malang: IKIP Malang, 1995), h. 1

${ }^{5}$ H. Muhammad Daud Ali, Pendidikan Agama Islam, (Jakarta: Raja Grafindo Persada, 2011), h. 396

${ }^{6}$ Yusufhadhi Miarso, Teknologi Komunikasi Pendidikan, (Jakarta: Rajawali, 1986), h. 5
} 
Menurut S. Nasution, pengertian teknologi pendidikan meliputi pengertian secara mikro dan pengertian secara makro. Secara mikro adalah teknologi pendidikan merupakan media komunikasi yang dimanfaatkan dalam pendidikan yang mencakup alat-alat teknologi pendidikan yang bersipat hardware. ${ }^{7}$

Secara makro dikutip oleh Sudjarwo S. Teknologi pendidikan adalah penerapan pengetahuan ilmiah tentang belajar dan kondisi belajar, untuk meningkatkan efektivitas dan efisiensi dalam mengajar dan latihan. Secara implicit, adalah menetapkan prinsipprinsip ilmiah, teknologi pendidikan adalah menerapkan teknik-teknik testing empiris untuk meningkatkan situasi belajar.

\section{Macam-Macam Teknologi}

Teknologi telah merupakan bahagian integral dalam setiap masyarakat, makin maju suatu masyarakat, makin banyak teknologi yang dikembangkan dan digunakan. ${ }^{8}$ Teknologi berkembang dengan maju, cukup banyak ragam dan bentuknya. Dari macam-macam teknologi sangat membantu dalam kehidupan manusia saat ini. Ada 7 macam teknologi canggih merupakan jenis-jenis teknologi informasi dan komunikasi yang berperan penting untuk memudahkan manusia melaksanakan tugas-tugas kehidupannya. Macam-macam teknologi tersebut adalah: ${ }^{9}$

a. Hand phone (Hp), telepon seluler (ponsel), atau telepon genggam. Teknologi informasi ini bisa dikatakan salah satu kebutuhan primer manusia setelah makan, pakaian dan perumahan. Dengan Hp informasi menyebar cepat dan siapapun bisa menjadi sumber informasi.

b. Laptop, notebook atau net book.

Latop merupakan media yang sangat membantu rutinitas pekerjaan seseorang, keuntungannya:

- Produktivitas pekerjaan dapat dipertahankan

- Informasi yang selalu uptudate dan kemudahan akses data. ${ }^{10}$

c. Komputer atau Pc. Ini terdiri dari perangkat keras dan lunak untuk mengolah, menyimpan dan menampilkan informasi.

\footnotetext{
${ }^{7}$ S. Nasution, Teknologi Pendidikan, (Jakarta: Bumi Aksara, 1994), h. 1

${ }^{8}$ Yusuf Hadi Miarso, Menyemai Benih Teknologi Pendidikan, (Jakarta: Kencana, 2007), h. 542

${ }^{9} 2014$ Kizzio.co.

${ }^{10}$ Wikipedia.com
} 
d. Tablet Pc

Perangkat teknologi ini adalah laptop atau computer portable yang berbentuk seperti buku.

e. Internet

Internet atau "inter-network" adalah seluruh jaringan computer yang berhubungan secara global melalui protocol pertukaran paket informasi (TPC/IP) yang menyediakan layanan email dan www (Word Wide web)

f. Televisi

Televisi adalah media elektronik yang menampilkan gambar dan suara (audio visual) atau gambar bergerak secara langsung.

g. Kamera digital.

\section{Landasan Pemanfaatan Teknologi}

Dalam buku Pendidikan Agama Islam Muhammad Daud Ali mengungkapkan pandangan al-Qur'an tentang teknologi, mengundang kita untuk melihat sekian banyak ayat-ayat yang berbicara tentang alam semesta. Menurut para ahli terdapat sekitar 750 ayat al-Qur'an yang berbicara tentang alam materi dan fenomenanya yang memerintah manusia untuk mengetahui dan memanfaatkan alam. Secara tegas dan berulang-ulang al-Qur'an menyatakan bahwa alam semesta diciptakan dan ditundukkan bagi (kepentingan manusia, seperti yang disebutkan pada awal surat al-jatsiayah (45) ayat 13 yang artinya (lebih kurang)," dan dia menundukkan untukmu apa yang ada di langit dan apa yang ada di bumi semuanya (sebagai rahmat) darinya...". Penundukan tersebut, secara potensial, terlaksana secara sunnatulloh (hukum-hukum yang ditetapkan Allah pada alam) dan kemampuan yang dianugrahkan-Nya pada manusia. Al-Qur'an menyebutkan sifat dan ciri-ciri alam semesta (sabagaimana telah disebutkan dalam butir Manusia dan Alam Semesta di muka), ditambahkan antara lain: (1) segala sesuatu di alam semesta mempunyai sifat, ciri dan hukum yang di dalam al-Qur'an surat al-Ra'd (13) ayat 8 disebut ukuran. (2) semua yang berada di alam semesta tunduk kepada-Nya. "Hanya kepada Allahlah tunduk segala (yang ada) dilangit dan (yang ada) di bumi secara sukarela maupun karena terpaksa....", demikian makna firman Allah pada awal ayat 15 surat al-Ra'd (13). (3) benda-benda alam, apalagi yang tidak bernyawa, tidak diberi kemampuan untuk memilih, sepenuhny untuk kepada Allah melalui hukum-hukum-Nya. Dalam surat al-Fussilat (41) ayat 11 terdapat 
firman Allah yang artinya (lebih kurang) sebagai berikut: "kemudian, Dia menuju penciptaan langit dan langit itu masih merupakan asap. Lalu dia Allah berkata kepadanya dan kepada bumi: datanglah (tunduklah) kamu berdua kepada perintah-Ku dengan suka rela atau terpaksa, keduanya (langit dan bumi) berkata: kami datang tunduk dan sukarela.". selain sifat, ciri-ciri, dan hukum Alla pada alam semesta, tiga diantaranya telah disebut diatas, manusia diberi kemampuan untuk mengetahui sifat-sifat, ciri-ciri, dan hukum-hukum yang berkaitan dengan alam semesta, sebagaimana diinformasikan oleh firman-Nya dalam al-Qur'an surat al-Baqarah (2) ayat 31, “Allah mengajarkan kepada Adam nama-nama (benda) semuanya”. Yang dimaksud dengan nama-nama pada ayat tersebut adalah sifat, ciri-ciri dan hukum suatu benda. Dengan itu manusia berpotensi untuk mengetahui rahasia alam semesta. Adanya potensi itu dan tersedianya lahan atau bahan ciptaan Allah serta ketidak mampuann alam semesta membangkang (tidak patuh) terhadap perintah dan hukum-hukum Allah, memungkinkan ilmuan secara pasti mengetahui hukum-hukum alam yang disebut sunnatullah diatas. Karena itu manusia berpotensi untuk memanfaatkan alam yang telah ditundukkan Allah itu. Keberhasilan manusia memanfaatkan alam merupakan buah ilmu pengetahuan dengan bantuan teknologi (IPTEK).

Al-qur'an memerintahkan manusia untuk terus berupaya meningkatkan kemampuan ilmiahnya dalam surah Al-'Alaq ayat 1-5 dijelaskan:

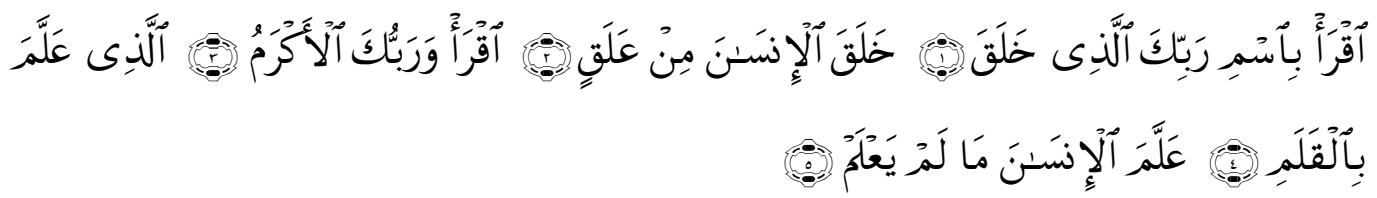

“1. bacalah dengan (menyebut) nama Tuhanmu yang Menciptakan, 2. Dia telah menciptakan manusia dari segumpal darah. 3. Bacalah, dan Tuhanmulah yang Maha pemurah, 4. yang mengajar (manusia) dengan perantaran kalam[1589], 5. Dia mengajar kepada manusia apa yang tidak diketahuinya."

\section{Hasil Belajar}

\section{Pengertian}

Pada dasarnya hasil belajar adalah kemampuan seseorang untuk melakukan sesuatu dari kegiatan belajar. Kemampuan itu diperoleh karena pada mulanya kemampuan itu 
belum ada. Terjadinya proses perubahan dari belum mampu menjadi mampu yang terjadi dalam pola sikap dan perilaku menandakan telah adanya hasil belajar.

Menurut Kunandar hasil belajar adalah kemampuan siswa dalam memenuhi suatu tahapan pencapaian pengalaman belajar dalam suatu kompetisi dasar, hasil belajar silabus berfungsi sebagai petunjuk tentang perubahan perilaku yang akan dicapai oleh siswa sehubungan dengan kegiatan belajar yang dilakukan sesuai dengan kompetensi dasar dan materi dasar yang dikaji. Hasil belajar bisa berbentuk pengetahuan,, keterampilan maupun sikap. ${ }^{11}$

Dalam dunia pendidikan hasil belajar adalah hasil yang diperoleh seseorang dalam usaha belajarnya. Hal ini dapat kita lihat dalam kemampuan siswa menyerap bahan pelajaran, kemampuan siswa tersebut dapat kita lihat dari sikap, perilaku, dan keterampilan yang dimiliki anak setelah proses belajar mengajar.

Hasil belajar adalah kemampuan-kemampuan yang dimiliki siswa setelah ia menerima pengalaman belajarnya. Hasil belajar merupakan pencapaian bentuk perubahan perilaku yang cenderung menetap dari ranah kognitif, afektif dan psikomotorik dari proses belajar yang dilakukan dalam waktu tertentu. ${ }^{12}$

Menurut A.J. Romiszowski dalam buku karangan Mulyono Abdurrahman, hasil belajar merupakan keluaran (outputs) dari suatu sistem pemrosesan masukan (inputs). Masukan dari sistem tersebut berupa macam-macam informasi. ${ }^{13}$ Pendapat lain bahwa hasil belajar adalah kemampuan siswa dalam memenuhi tahapan pencapaian pengalaman belajar dalam satu kompetensi dasar. ${ }^{14}$ Jadi dapat disimpulakan hasil belajar adalah perubahan perilaku pada siswa baik kognitif, afektif dan psikomotorik setelah mendapat pengalaman belajar.

\section{Jenis-Jenis Hasil Belajar}

Menurut pendapat Bunyamin Bloom dalam buku Nana Sujana membagi tiga macam hasil belajar

1. Ranah kognitif

Ini berkenaan dengan hasil belajar intelektual dan dibagi enam aspek

${ }^{11}$ Nana Sudjana, Penilaian Proses Hasil Belajar Mengajar, (Bandung: PT. Remaja Rosdakarya, 2001), h. 3.

${ }_{12}$ Asep Jihad dan Abdul Haris, Evaluasi Pembelajaran, (Yogyakarta: Multi Pressindo, 2012), h. 14

${ }^{13}$ Mulyono Abdurrahman, Anak Berkesulitan Belajar, (Jakarta: Rinekacipta, 2012), h. 26

${ }^{14}$ Kunandar, Guru Profesional (Jakarta: PT Raja Grafindo Persada, 2007), h. 251 
a. Hapalan atau ingatan yaitu kemampuan menghapal merupakan kemampuan kognitif yang paling rendah. Kemampuan ini merupakan kemampuan memanggil kembali fakta yang disimpan dalam otak digunakan untuk merespon suatu masalah.

b. Kemampuan pemahaman adalah kemampuan untuk melihat hubungan fakta dengan fakta. Menghapal fakta tidak lagi cukup, karena pemahaman menuntut pengetahuan akan fakta dan hubungannya. Pemahaman adalah kesanggupan memahami lebih tingkat daripada pengetahuan misalnya menjelaskan, meguraikan, membedakan dan merumuskan

c. Penerapan atau aplikasi yaitu penerapan penggunaan materi. Siswa dituntut mampu menggunakan materi yang dipelajarinya ke dalam situasi baru. Misalnya menghitung, membuktikan, menemukan dan melengkapi.

d. Analisa yaitu sebuah proses analisis teoritis dengan menggunakan kemampuan akal. Analisis adalah usaha memiliki integrasi menjadi unsur-unsur atau bagianbagian sehingga jelas susunannya. Misalnya menunjukkan hubungan antar variable atau menganalisa.

e. Sintesis yaitu kemampuan memadukan konsep sehingga menemukan konsep baru pada tahap ini siswa diminta untuk melakukan generalisasi bagian-bagian atau hal-hal yang efektif menjadi suatu keseluruhan. Misalnya dengan cara mengkombinasikan, menghubungkan dan menyimpulkan

f. Evaluasi yaitu kemampuan melakukan evaluatif atas penguasaan matei pengetahuan. Evaluasi adalah penilaian terhadap tingkat keberhasilan siswa mencapai tujuan yang telah ditetapkan. Hasil penilaian evalusi tersebut dinamakan hasil belajar. Misalnya dengan cara membuktikan, menemukan, mengevaluasi, mengoreksi dan menyimpulkan. ${ }^{15}$

2. Ranah Afektif

Menurut Purwanto ranah afektif berkenaan dengan sikap dan nilai dan dibagi lima, yaitu:

a. Penerimaan atau menaruh perhatian. Adalah kesediaan menerima rangsangan dengan memberikan perhatian kepada rangsangan yang datang kepadanya.

\footnotetext{
${ }^{15}$ Evaline dan Hartini Nara, Teori Belajar dan Pembelajaran (Bogor: Ghalia Indonesia, 2011), h. 8-9
} 
b. Partisipasi atau merespon adalah kesediaan memberikan respon dengan berpartisipasi

c. Penilaian atau penentuan sikap adalah kesediaan untuk menentukan pilihan sebuah nilai dari rangsangan tersebut.

d. Organisasi adalah kesediaan mengorganisasikan nilai nilai yang dipilihnya untuk menjadi pedoman yang mantap dalam perilaku.

e. Krakterstik nilai adalah menjadikan nilai nilai yang diorganisasikan untuk tidak hanya menjadi pedoman perilaku tetapi menjadi bagian dari peribadi dalam perilaku sehari-hari.

3. Ranah psikomotorik.

Menurut Popi Sopianti dan Sohari Sahrani hasil belajar psikomotorik tampak dalam keterampilan dan kemampuan bertindak individu..

Menurut Ahmad Tafsir hasil belajar atau bentuk perubahan tingkah laku yang diharapkan itu merupakan suatu target atau tujuan pembelajaran yang meliputi tiga aspek. Inilah sebenarnya indikator hasil belajar yaitu

1. Tahu, mengetahui (knowing)

2. Terampil melaksanakan atau mengerjakan yang ia ketahui (doing)

3. Melaksanakan yang ia ketahui itu secara rutin dan konsekuen (being). ${ }^{16}$

Pendapat syaiful bahri djamaroh dalam buku strategi belajar mengajar tentang petunjuk bahwa suatu proses belajar mengajar dianggap berhasil adalah:

1. Daya serap terhadap bahan pengajaran yang diajarkan mencapai prestasi tinggi,baik secara individual maupun kelompok.

2. Perilaku yang digariskan dalam tujuan pengajaran telah dicapai oleh siswa, baik secara individual maupun kelompok. Namun demikian, indikator yang banyak dipakai sebagai tolak ukur keberhasilan adalah daya serap.

\section{Fungsi Hasil Belajar}

Ada tiga fungsi hasil belajar

1. Alat untuk mengetahui tercapai tidaknya tujuan

${ }^{16}$ Ahmad Tafsir, Filsafat Pendidikan Islam Integrasi Jasmani, Rohani dan Kalbu Memanusiakan Manusia, (Bandung: Remaja Rosdakarya Offset, 2012), h. 224-225 
2. Umpan balik bagi perbaikan proses belajar mengajar, baik kegiatan siswa maupun strategi guru dalam mengajar.

3. Dasar dalam penyusunan laporan kemajuan belajar siswa kepada orangtuanya. ${ }^{17}$

\section{Faktor-Faktor yang Memengaruhi Hasil Belajar}

Menurut Slameto faktor-faktor yang mempengaruhi hasil belajar siswa antara lain:

1. Faktor internal (faktor dalam diri siswa) ini meliputi tiga faktor

a. Faktor jasmani: faktor kesehatan dan faktor cacat tubuh.

b. Faktor psikologi: intelegensi, bakat, motif, kematangan, kesiapan.

c. Faktor kelelahan: kelelahan jasmani dan kelelahan roohani

2. Faktor Ekstern (faktor dari luar diri siswa) ini meliputi tiga faktor

a. Faktor keluarga: cara orangtua mendidik, relasi antar anggota keluarga, suasana rumah, keadaan ekonomi keluarga.

b. Faktor sekolah: metode mengajar, kurikulum

c. Faktor masyarakat: kesiapan siswa dalam masyarakat, media massa, teman bergaul, bentuk kehidupan masyarakat. ${ }^{18}$

\section{Pemanfaatan Kawasan- Kawasan Teknologi Pendidikan dalam Meningkatkan Hasil Belajar}

Kawasan atau klasifikasi teknologi pendidikan bisa dilihat dari lima bidang garapan yaitu:

a. Desain, terdiri dari desain sistem pembelajaran, desain pesan, strategi pembelajaran dan karakteristik pembelajaran.

b. Pengembangan, terdiri dari teknologi cetak, teknologi audiovisual, teknologi berbasis computer dan teknologi terpadu.

c. Pemanfaatan, terdiri dari pemanfaatan media, difusi inovasi, impelementasi dan institusionalisasi serta kebijakan dan regulasi.

d. Pengelolaan, terdiri dari manajemen proyek, manajemen sumber, manajemen sistem penyampaian dan manajemen informasi.

\footnotetext{
${ }^{17}$ Nana Sudjana, Penilaian Proses Hasil Belajar Mengajar, (Bandung: Remaja Rosdakarya, 2001) hlm. 3

${ }^{18}$ Slameto, Belajar dan Faktor-Faktor yang Mempengaruhinya, (Jakarta: Rineka Cipta, 2003), hlm. 57
} 
e. Penilaian, terdiri dari analisis masalah, pengukuran ucuan patokan, evaluasi formatif dan evaluasi sumatif. ${ }^{19}$

Menurut kutipan Yusuf Hadi Miarso dari defenisi teknologi pendidikan yang dikemukakan oleh Seels dan Richy, dapat digambarkan tentang modifikasi teknologi pendidikan ada 6 kawasan:

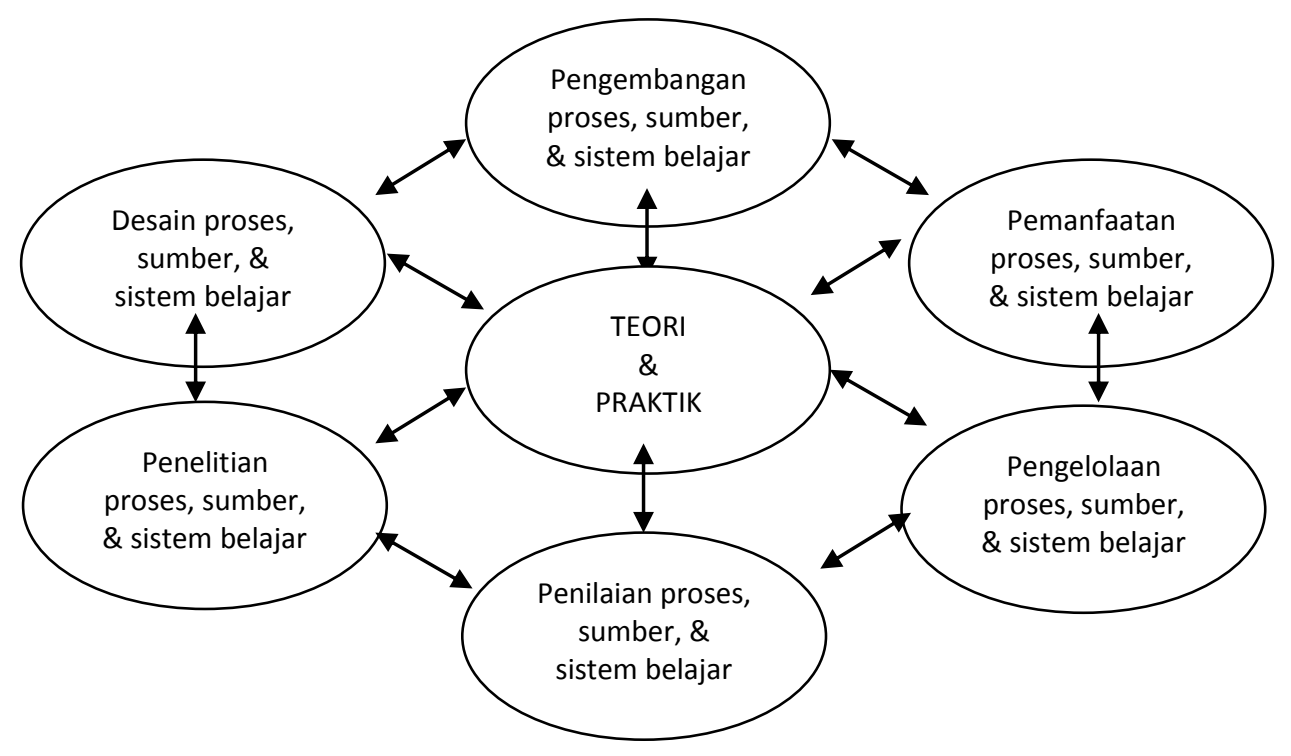

\section{a. Kawasan Desain}

Yang dimaksud dengan desain disini adalah proses untuk menentukan kondisi belajar dengan tujuan untuk menciptakan strategi dan produk. Kawasan desain paling tidak meliputi empat cakupan utama dari teori dan praktek, yaitu: (1) Desain sistem pembelajaran, (2) Desain pesan, (3) Strategi pembelajaran, (4) Karakteristik pembelajaran.

a) Desain sistem pembelajaran, yaitu prosedur yang terorganisasi, meliputi langkahlangkah: (1) Penganalisaan (proses perumusan apa yang akan dipelajari), (2) Perencanaan (proses penjabaran bagaimana cara mempelajarinya), (3) Pengembangan (proses penulisan dan pembuatan atau produksi bahan-bahan pelajaran), (4) Pelaksanaan (pemanfaatan bahan dan strategi), (5) Penilaian (proses penentuan ketetapan pembelajaran), dalam desain sistem. Pembelajaran, proses sama pentingnya dengan produk, sebab kepercayaan atas produk berlandaskan pada proses. 1995), h.1

${ }^{19}$ Ibrahim, Teknologi Pendidikan, Arti Kawasan dan Penerapannya di Indonesia, (Malang: IKIP Malang, 
b) Desain pesan, yaitu perencanaan untuk merekayasa bentuk pisik dari pesan agar terjadi komunikasi antara pengirim dan penerima, dengan memperhatikan prinsipprinsip perhatian, persepsi, dan daya tangkap. Fleming dan Levie membatasi pesan pada pola-pola isyarat, atau symbol yang dapat memodifikasi prilaku kognitif, afektif, dan psikomotorik. ${ }^{20}$

c) Strategi pembelajaran, yaitu spesifikasi untuk menyeleksi serta mengurutkan peristiwa belajar dalam suatu pelajaran. Dalam mengaplikasikan suatu strategi pembelajaran bergantung pada situasi belajar, sifat materi dan jenis belajar yang dikehendaki.

d) Karakteristik pemebelajaran, yaitu segi-segi latar belakang pengalaman pembelajaran yang mempengaruhi terhadap keefektifan proses belajarnya. Karakteristik pemeblajaran mencakup keadaan sosio-psiko fisik pembelajar. Secara psikologis, yang perlu mendapat perhatian dari karakteristik pembelajar yaitu berkaitan dengan kemampuannya, baik yang bersifat potensial maupun kecakapan nyata dan kepribadiannya, seperti sikap, emosi, motivasi serta aspek-aspek kepribadian lainnya

Kawasan desain merupakan satu hal yang sangat penting di dalam pembelajaran,tugas guru dan dosen dalam kawasan desain ini sangat penting yaitu untuk menentukan kondisi belajar,strateginya untuk menciptakan prodak atau hasil belajar yang baik.Jika mendesain pembelajaran tidak baik,maka strategipun salah,maka hasil belajarpun bisa berpengaruh negatif.

\section{b. Kawasan Pengembangan}

Pengembangan adalah proses penterjemahan spesifikasi desain kedalam bentuk fisik, di dalamnya meliputi: (a) Teknologi cetak, (b) Teknologi audio visual, (c) Teknologi berbasis computer, (d) Teknologi terpadu

Kawasan pengembangan berakar pada produksi media. Melalui proses yang bertahun-tahun perubahan dalam kemampuan media ini berakibat pada perubahan kawasan. Walaupun perkembangan buku teks dan alat bantu pembelajaran yang lain (teknologi cetak) mendahului film, namun kemunculan film merupakan tonggak sejarah dari gerakan audio-visual ke era teknologi pembelajaran sekarang ini.

${ }^{20}$ Yusuf Hadi Marso, Menyamai Benih Teknologi Pendidikan, (Jakarta: Kencana, 2007), h. 201 
Setelah guru dan dosen mendesain pembelajaran,tugas berikutnya adalah mengembangkan dalam bentuk teknologi cetak, audio visual,teknologi berbasis computer dan teknologi terpadu.sangat tidak benar jika seorang guru dan dosen sudah mendesain pembelajarannya dengan benar tapi tidak dikembangkan dengan memanfaatkan teknologi.

\section{c. Kawasan Pemanfaatan}

Pemanfaatan adalah aktivitas menggunakan proses dan sumber untuk belajar. Fungsi pemanfaatan sangat penting karena menbicarakan kaitan antara pembelajar dengan bahan atau sistem pembelajaran. Mereka yang terlibat dalam pemanfaatan mempunyai tanggung jawab untuk mencocokkan pembelajar dengan bahan dan aktivitas yang spesifik, menyiapkan pembelajar agar dapat berinteraksi dengan bahan dan aktivitas yang dipilih, memberikan bimbingan selama kegiatan, memberikan penilaian atas hasil yang dicapai pembelajar, serta memasukkannya kedalam prosedur organisasi yang berkelanjutan.

Kawasan pemanfaatan terdiri dari pemanfaatan media difusi inovasi, implementasi dan institusionalisasi serta kebijakan dan regulasi. Langkah-langkah merancang pemanfaatan media dalam belajar yaitu:Menganalisi pembelajar, Merumuskan tujuan, Memilih media dan bahan, Menggunakan media dan bahan, Melibatkan siswa, Penilaian dan revisi

Difusi inovasi yaitu proses berkomunikasi melalui strategi yang terencana dengan tujuan terjadinya perobahan. Implementasi dan institusionalisasi yaitu penggunaan bahan dan strategi pembelajaran dengan sungguh-sungguh. Kebijakan dan regulasi yaitu aturan dan tindakan yang mempengaruhi pemanfaatan teknologi pembelajaran

Tugas guru dan dosen dalam Kawasan pemanfaatan semakin berat yaitu memanfaatkan seluruh komponen pembelajaran dengan sungguh-sungguh agar tercapai tujuan pembelajaran yaitu terjadinya perubahan (bidang kognitif,afektif dan psikomotorik).

\section{d. Kawasan Pengelolaan}

Pengelolaan meliputi pengendalian teknologi pembelajaran melalui perencanaan, pengorganisasian, pengkoordinasian dan supervise. Kawasan pengelolaan bermula dari administrasi pusat media, program media dan pelayangan media. Pembauran 
perpustakaan dengan program media membuahkan pusatdan ahli media sekolah. Program media sekolah ini menggabungkan bahan media cetak dan mencetak sehingga timbul peningkatan penggunaan sumber-sumber teknologikal dalam kurikulum. Kawasan pengelolaan terdiri dari menajemen proyek, menajemen sumber, menajemen penyampaian dan menajemen informasi.

Dalam kawasan pengelolaan tugas guru dan dosen harus mampu melaksanakan manajemen pembelajaran yaitu perencanaan, pengorganisasian, pengkordinasian dan supervisi.

\section{e. Kawasan Penilaian}

Penilaian merupakan proses penentuan memadai tidaknya pembelajaran dan belajar, mencakup: Analisis masalah, Pengukuran acuan patokan, (evaluasi), Penilaian formatif, dan Penilaian sumatif. Analisis masalah yaitu penentuan sifat masalah dengan mengumpul informasi dan mengambil keputusan. Pengukuran acuan patokan yaitu menentukan kemampuan. Pembelajar menguasai materi dan sesuai dengan tujuan, ukirannya adalah pengetahuannya, sikapnya dan keterampilannya. Evaluasi formatif adalah untuk mengetahui hasil pengajaran yang sedang berlangsung . evaluasi sumatif adalah mengetahui hasil setelah selesai pengajaran efektif atau tidak.

Dalam kawasan penilaian dibedakan pengertian antara penilaian program, proyek, produk. Penilaian program evaluasi yang menaksir kegiatan pendidikan yang memberikan pelayangan secara berkesinambungan dan sering terlibat dalam penyusunan kurikulum. Penilaian proyek evaluasi untuk menaksir kegiatan yang dibiayai secara khusus guna melakukan suatu tugas tertentu dalam suatu kurun waktu. Penilaian bahan (produk pembelajaran)evaluasi yang menaksir kebaikan atau manfaat isi yang menyangkut benda-benda pisik, termasuk buku, pedoman kurikulum, film, pita rekaman, dan produk pembelajaran lainnya.

Dalam kawasan penilaian tugas guru dan dosen adalah menganalisis masalah dan melaksanakan pengukuran. Menganalisis masalah yaitu penentuan sifat masalah dengan mengumpul informasi dan mengambil keputusan.Pengukuran yaitu menentukan kemampuan siswa menguasai materi sesuai dengan tujuan. Ukurannya sebenarnya menyangkut aspek kognitif,afektif dan psikomotorik. Di kawasan inilah tugas paling 
berat bagi guru dan dosen, jika guru dan dosen tidak konsisten terhadap aturan penilaian akan berpengaruh terhadap hasil belajar siswa

\section{f. Kawasan Penelitian}

Minimal ada empat sebab yang melatar belakangi orang melakukan penelitian termasuk dalam mengembangkan teknologi pembelajaran sebagai bidang kajian menurut Sukma Dinata (2008) yaitu pertama, karena pengetahuan, pemahaman dan kemampuan manusia sangat terbatas dibandingkan dengan lingkungannya yang begitu luas. Banyak hal yang tidak diketahui, dipahami, tidak jelas dan menimbulkan keraguan dan pertanyaan. Kedua, manusia memiliki dorongan untuk mengetahui. Manusia selalu bertanya, apa itu, bagaimana itu, mengapa begitu dan sebagainya. Bagi kebanyakan orang jawaban-jawaban sepintas dan sederhana sudah memberikan kepuasan, tetapi bagi orangorang tertentu para ilmuan, peneliti dan para pemimpin dibutuhkan jawaban yang begitu mendalam. Ketiga, manusia di dalam kehidupannya selalu dihadapkan kepada masalah, tantangan, ancaman, kesulitan baik di dalam dirinya, keluarganya, masyarakat sekitarnya serta dilingkungan kerjanya. Keempat, manusia tidak merasa puas dengan apa yang telah dicapai, dikuasi dan dimilikinya, ia ingin selalu lebih baik, lebih ingin memberikan kemudahan, selalu ingin menambah dan meningkatkan kekayaan dan fasilitas hidupnya. Dari hasil penelitian manusia dapat mengembangkan pengetahuan yang bermakna bagi kehidupan ilmiah dan sosial.

Kawasan penelitian menjadi tugas seorang guru dan dosen,yaitu meneliti hasil pembelajaran yang telah dicapai oleh siswa dan mahasiswa,bila hasil belajar siswa dan mahasiswa baik,maka strategi yang sudah dilaksanakan tetap dipertahankan dan ditingkatkan,tetapi bila hasil belajar tidak tercapai maka harus dicari kesalahannya mulai dari kawasan desain dan kawasan-kawasan berikutnya.

Enam kawasan teknologi pendidikan yang diuraikan diatas merupakan hubungan yang saling berkaitan satu sama lain, tidak bisa dipisahkan. Dalam pemanfaatan kawasankawasan tersebut harus berurutan. Jika guru dan dosen memanfaatkan kawasan-kawasan tersebut dalam pembelajaran, maka akan dapat mendukung tercapainya hasil belajar yang baik. 


\section{E. PENUTUP}

Uraian uraian di atas berkaitan dengan pemanfaatan kawasan-kawasan teknologi pendidikan dalam meningkatkan hasil belajar.Guru dan dosen diharapkan mampu memanfaatkan kawasan-kawasan teknologi pendidikan tersebut dalam melaksanakan pembelajaran.Jika guru dan dosen berusaha memanfaatkan kawasan-kawasan tersebut.maka itu sudah merupakan satu pendukung pencapaian hasil belajar yang baik.

\section{DAFTAR REFERENSI}

Ahmad Tafsir, Filsafat Pendidikan Islam Integrasi Jasmani, Rohani dan Kalbu Memanusiakan Manusia, Bandung: Remaja Rosdakarya Offset, 2012

Asep Jihad dan Abdul Haris, Evaluasi Pembelajaran, Yogyakarta: Multi Pressindo, 2012

Evaline dan Hartini Nara, Teori Belajar dan Pembelajaran, Bogor: Ghalia Indonesia, 2011

H. Muhammad Daud Ali, Pendidikan Agama Islam, Jakarta: Raja Grafindo Persada, 2011

http: // istana ilmu, com/ Pengaruh Teknologi Pendidikan dalam Lembaga Pendidikan dan Pelatihan/ html.

Ibrahim, Teknologi Pendidikan, Arti Kawasan dan Penerapannya di Indonesia, Malang: IKIP Malang, 1995

Imam Sukardi, dkk, Pilar Islam Bagi Pluralisme, Solo: Tiga Serangkai, 2003

Mulyono Abdurrahman, Anak Berkesulitan Belajar, Jakarta: Rinekacipta, 2012

Nana Sudjana, Penilaian Proses Hasil Belajar Mengajar, Bandung: PT. Remaja Rosdakarya, 2001

S. Nasution, Teknologi Pendidikan, Jakarta: Bumi Aksara, 1994

Slameto, Belajar dan Faktor-Faktor yang Mempengaruhinya, Jakarta: Rineka Cipta, 2003

Wikipedia.com

Yusuf Hadi Marso, Menyamai Benih Teknologi Pendidikan, Jakarta: Kencana, 2007

Yusuf Hadi Miarso, Teknologi Komunikasi Pendidikan, Jakarta: Rajawali, 1986 